\title{
圧縮変形したステンレス鋼巻線の焼結挙動
}

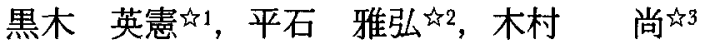 \\ 品1 広島大学工学部第一類，干724 東広島市鏡山1-4-1. \\ 的2 広島大学大学院, 干724 東広島市鏿山1-4-1，〔(現) 島津製作所]

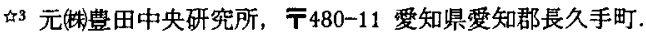

\section{Sintering of Wire-wound Compacts after Pressing and Deformation}

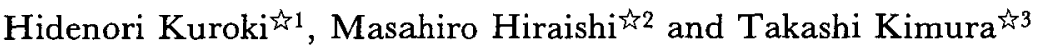 \\ At Department of Mechanical Engineering, Faculty of Engineering, Hiroshima University, 1-4-1 Kagamiyama \\ Higashi-hiroshima 724. \\ 42 Department of Material Engineering, Graduate School, Hiroshima University, 1-4-1 Kagamiyama Higashi- \\ hiroshima 724, Present address: Shimazu Corp. \\ \{3 Toyota Central R \& D Labs., Inc., Nagakute-cho Aichi-gun 480-11, Present address: Tokyo Sintered Metals \\ Co. Ltd.
}

Received April 30, 1991

\begin{abstract}
$18 \mathrm{Cr}-8 \mathrm{Ni}$ stainless steel wires $0.160 \mathrm{~mm}$ and $0.035 \mathrm{~mm}$ in diameters were wound in layers on core rods of the same steel. Before sintering in hydrogen, the wire layers were cold-pressed in the direction along core axis to form flat contact areas between wires, with widths of one third of the each original wire diameter. Welds between contacting surfaces of wires were observed on sections of the wire layers by optical and scanning-electron microscopes.

The initial stage of sintering begins by the formation of micro welds at some points between contacting surfaces. The welds grow and coalesce with each other eliminating micro pores between them to occupy whole the flat contacts between wires. The activation energy of welding $60 \%$ of the flat area is lower than that for grain boundary diffusion of iron in a stainless steel. The energy of welding $90 \%$ is similar to that for volume diffusion. Welding rates during the initial stage of sintering are independent on wire diameter. The growth of a whole neck proceeds more rapidly between smaller wires than between larger ones. Curvatures of the necks are independent on wire diameter.
\end{abstract}

\section{I 緒 言}

焼結機構を定量的以研究する場合，巻線モデルは，軸 を通る断面上に線の断面を粉末のモデルとして規則正し く並べることが容易なので，個別粒子ではなく多数の粒 子から成る粉末集合体のモデルとして適している1)。

ところでこの巻線モデルに対して, 従来大きな冷間圧 縮を行った例はない，しかし一般に焼結に上る組織形成 では，粉末粒子同士または線同士の接触面の形状が焼結 に影響する重要な要素の一つと考えられる22。従って, 通常の機械部品のよらに粉末をむず王縮成形し，続いて 焼結を施して製造する場合，压縮で生じた粒子同士の变
形接触面の状況が焼結を左右するであるう。しかも実際 の生産では燒結が比較的短時間で齐まされる場合が多い ので，粒子間の変形接触面の微視的凹凸部で起こる初期 焼結過程を解明することが，工業的な燒結を理解する上 で極めて重要な課題であると思われる.

そこで, 本研究ではステンレス鋼巻線試料を軸に平行 に冾間加圧し，線同士の間で圧縮変形によって生した接 触面の接合過程について，各種焼結条件の影響を調查し た.

$$
\text { II 実 験 方 法 }
$$

\section{II -1 試料の作製}


（a）構造：概略を Fig. 1 亿示す、線としては，各種焼 結条件の影響を調べるための標準的な試料にステンレス 鋼 SUS304 $(18 \mathrm{Cr}-8 \mathrm{Ni}), \phi 0.160 \mathrm{~mm}$ のむのを用いた外， 線径の影響を調べるためには同じ材質の $\phi 0.035 \mathrm{~mm} の$ 線も用いた．巻き方は，耐力に等しい張力を与えながら 1 層に 17 18回巻き，合計で 5 層巻いた.フランジはネ ジを緩めれば可動となるので，冷間圧縮時及び加圧焼結 時に線に荷重を加えることができ，またネジ締めれば 変形した巻線の密着状態を維持できるよらになってい る.

(b) 圧縮：粉末の加圧成形にならって巻線試料を圧縮 し，Fig. 2 に示寸変形を線の断面に与兄た。それには Fig. 3 のように上下パンチの間で加圧ジグを介して試料

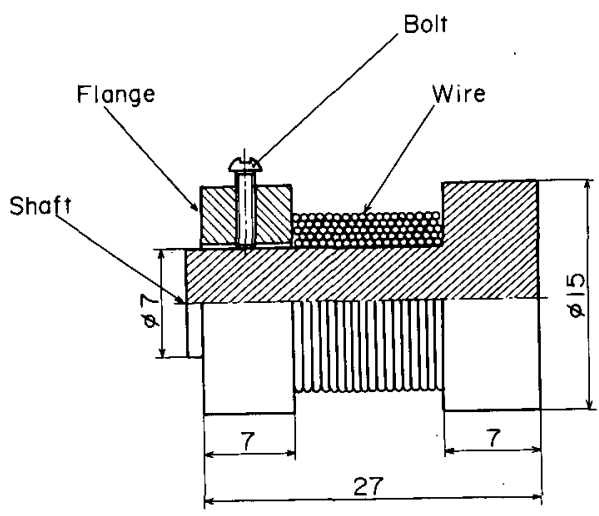

Fig. 1 The structure of a wire-wound compact with a mobile flange and a screw to fix it.

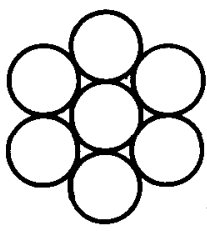

(a)

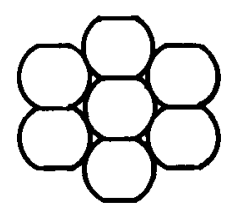

(b)
Fig. 2 Deformation of the wound wire layers. (a) before pressing, (b) after pressing

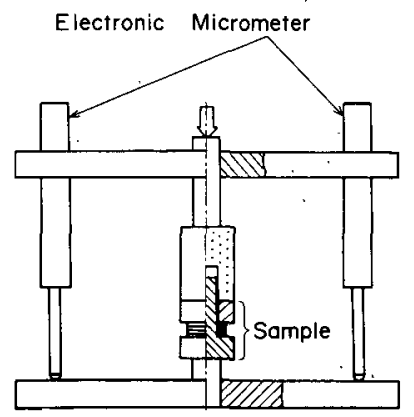

Fig. 3 The pressing tool set for wire-wound compacts instrumented with a couple of electronic micrometers.
をはさみ，電気マイクロメータで变位を読み取りつつ加 圧した．この際，接触した部分の長さが線自体の直径の ほぼ1/3になるまで変形したが，それに必要な荷重は予 め圧縮試験を行って $\phi 0.160 \mathrm{~mm}$ の試料では $3330 \mathrm{~N}$, $\phi 0.035 \mathrm{~mm}$ の試料では $650 \mathrm{~N}$ に決定した.

（c）焼結：焼結は，一定温度に保持して純水素を通し ている炉中に試料を挿入して行い，所定の時間が経過し た後，同雾囲気のまま冷却帯に移動して冷却した，温度 は $1263 \mathrm{~K}$ 及び $1363 \mathrm{~K}, 1463 \mathrm{~K}$ を採用し，各温度で保持 時間を変えた。また，試料に錘を載せた状態で加任焼結 西行った。

な持焼結時間の值に対しては，試料の昇温中における 抁散の遅れ量及び降温中における扗散の継続量を，焼結 温度に拈ける時間に換算して ${ }^{3)}$ 補正した。 これによる補 正は最も大きい $1263 \mathrm{~K}$ の場合に $489 \mathrm{sec}$ の隇算であっ た.

\section{II-2 焼結状況の評価}

焼結した試料は樹脂に埋め込んで断面を研磨し, 光学 顕徽鏡ないし走查型電子顕微鏡で観察した。

(a) 焼結率：圧縮と焼結を済ませた試料の断面上で， 王樎によって変形・接触した部分の焼結度合を表す值と して焼結率を定義した。

$$
\text { 焼結率= } \mathrm{A} / \mathrm{A}
$$

ここで Fig. 4 のように

$\mathrm{A}_{0}$ : 圧縮によって変形・接触し, 線間の距離が $0.6 \mu \mathrm{m}$ (これは，向かい合う変形面の間の距離として，未 焼結試料中の隣接 2 線間で実測された最大值であ る）以下になった部分の長さ。

$\mathrm{A}: \mathrm{A}_{0}$ 中で焼結によって接合した部分の長さの総和. な敞焼結率の測定は第三周の線同士について行った. この層では巻線の両端がフランジに直接に接触し， 同一層内の線同士の接触変形が確実に起こると考兄 られるからである。

(b) 変形・接触部の長さ：本来ならば上記の $\mathrm{A}_{0}$ の値は 焼結前に測定しなければならないが，その測定は難しい ので，本実験では焼結後の断面上で測定し，それが焼結 前の同じ試料の同じネックに扣ける值と変わっていない ことを確認する．まずFig. 5 のよらに㮱結後の試料の断 面上で B を実測し，線径に等しい円上に $\mathrm{B}$ と同間隔の 平行線を引き，弦の長さ $\mathrm{A}_{0}{ }^{\prime}$ を求める，線が塑性变形す るので， $A_{0}$ はこの $A_{o}^{\prime}$ と等しくはないが，本実験の場

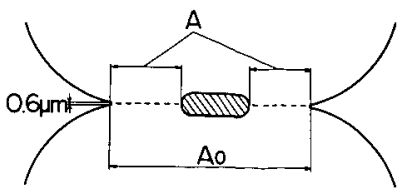

Fig. 4 Measurement of the sintered ratio at a contact between wires. 


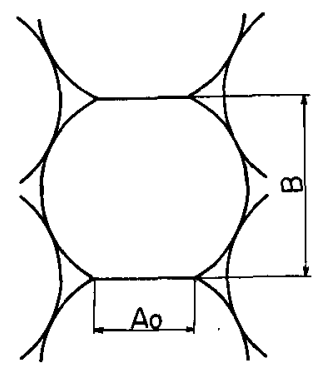

(a)

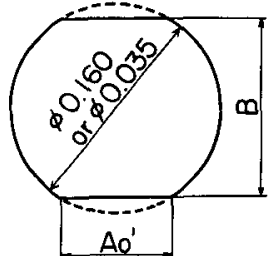

(b)
Fig. 5 Determination of the width of flat contacting surfaces between wires.

(a) measuring $A_{0}$ and $B$

(b) determining $A_{o}$ ' from $B$

合は B の值が平均値 $0.148 \mathrm{~mm}$ の上下 $7 \%$ の範囲に入っ ているので，同じネックの $\mathrm{A}_{0}$ と $\mathrm{A}_{0}{ }^{\prime}$ は近似的に比例乙 ていると考えてよいである5，すなわら，焼結による变 化がなければ比 $\mathrm{A}_{\mathrm{o}} / \mathrm{A}_{\mathrm{o}}$ ’ は一定值を取ると推測される. 従って焼結条件の異なる試料について $\mathrm{A}_{0} / \mathrm{A}_{\mathrm{o}}$ 'の値を比 べれば， $A_{o}$ の值が烇結中に变化したかどらかを判断で きると思われる．以上の考兄を適用したところ，後述の 上5に $\phi 0.160 \mathrm{~mm}$ の試料では焼結前の $\mathrm{A}_{0}$ の值と焼結後 の同じ試料打ける值とが変わっていないので，焼結後 の值を分母に用いるだけで焼結率が求められる.しかし， $\phi 0.035 \mathrm{~mm}$ の試料では, 後揭 Fig. 7 のよらに高温・長時 間の焼結に上って当初の变形・接触部の外側まで接合が 進むので，次の方法で焼結の進行による $\mathrm{A}_{\mathrm{o}}$ 值の増加の 影響を補正する。焼結初期の試料て観察される接触面の ネックは接触面より大きくなっていないはずであるか ら, その段階では,

$$
\mathrm{A}_{0}=\mathrm{CA}_{0}^{\prime}
$$

であろう。この比例定数 $\mathrm{C}$ はネックが变形面の外側ま で成長していない試料を観察して得られる。それには低 温, 短時間の焼結を行った試料を 3 個選び, $\mathrm{A}_{0} / \mathrm{A}_{0}$ 'の值 を平均した。この方法で求めた $\mathrm{C}$ と各試料の $\mathrm{A}_{\mathrm{o}}^{\prime}$ の積 を（1）式の $A_{0}$ の代わりに用いれば，

$$
\text { 補正焼結率 }=\mathrm{A} / \mathrm{CA}_{\circ} \text {, }
$$

である.

(c) ネックの曲率半径 : 線間接触部の外側表面の曲率 半径である.50000倍の写真と画像解析装置を用いて断 面の輪郭線上の 3 点の匧標を測定し，その 3 点を通る円 の半径を算出して曲率半径とした。

\section{III 結果}

III-1 変形・接触部の長さの変化

焼結率を求める䟢，(1) 式の $\mathrm{A}_{\mathrm{o}}$ として焼結前の長さ の代わりに焼結後の長さを用いて良いかどらかを検討す るため，本実験の全試料仁ついて焼結後の $\mathrm{A}_{0}$ と Fig. 5 に図解した $\mathrm{A}_{\mathrm{o}}{ }^{\prime}$ の比を調べた. 成形・烇結条件に対して
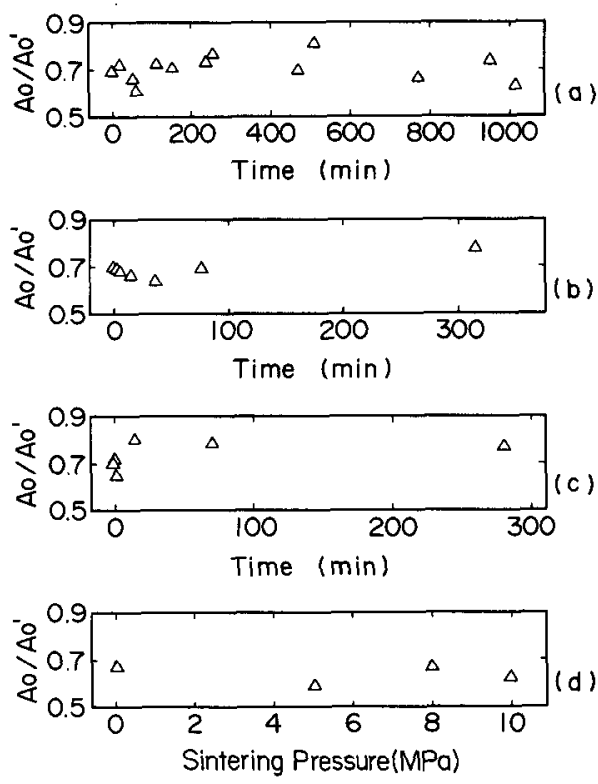

Fig. $6 \quad A_{0} / A_{o}^{\prime}$ ratios in $0.160 \mathrm{~mm}$ wire compacts.

(a) sintered at $1263 \mathrm{~K}$

(b) sintered at $1363 \mathrm{~K}$

(c) sintered at $1463 \mathrm{~K}$

(d) sintered under various pressures at $1263 \mathrm{~K}$ for $52 \mathrm{~min}$
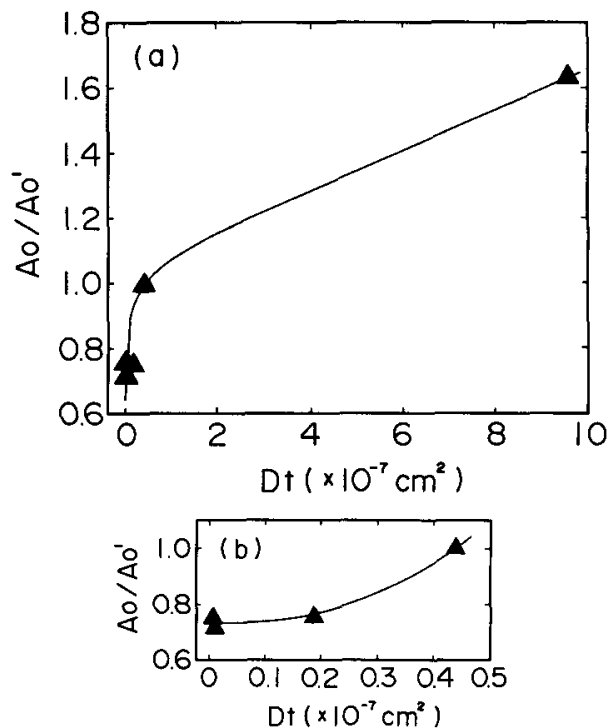

Fig. $7 \quad \mathrm{~A}_{\mathrm{o}} / \mathrm{A}_{\mathrm{o}}{ }^{\prime}$ ratios in $0.035 \mathrm{~mm}$ wire compacts.

(a) all the obtained data

(b) enlarged figure of (a)

$\mathrm{A}_{\mathrm{o}} / \mathrm{A}_{\mathrm{o}}{ }^{\prime}$ の值は $\phi 0.160 \mathrm{~mm}$ の試料では Fig. 6, また $\phi 0.035 \mathrm{~mm}$ の試料では Fig. 7 のようになった. ただし Fig. 7 では焼結温度と時間を払散量に比例する Dt でま とめて括り，同図 (b) は Dt が小さい段階の詳細図であ る. Fig. 6 Kよると $\phi 0.160 \mathrm{~mm}$ の試料では多少ばらつき があるが， $\mathrm{A}_{\mathrm{o}} / \mathrm{A}_{0}$ ’の值は焼結温度及び時間，また加圧焼 
結における管結中の加圧力に関係なく，常にほぼ一定の 値を示すので，接触部の長さ $A_{0}$ 渀結前の値と汪とん ど変わっていないと推測される。すなわち，これらの試 料では焼結が変形・接触部の内側で起こり, 外に向かっ て広がっていない，従って，焼結度合を表すための基準 值 $\mathrm{A}_{\circ}$ として焼結後に測定した值を用いることは， $\phi 0.160 \mathrm{~mm}$ の試料の場合は妥当であろう.

一方 $\phi 0.035 \mathrm{~mm}$ の試料では, Fig. 7 のよに Dt が大 きい場合，すなわら高温・長時間の試料で，明らかに A ${ }^{d} / A_{0}{ }^{\prime}$ の值が初期に比べて高くなって括り, 変形・接触 部の外側まで接合が進んでいることが分かる。従って， この線径では，焼結後に求めた $\mathrm{A}_{0}$ を焼結度合を表す值 （焼結率）の基準として用いることは不適当であり，(3) 式のよらな補正が必要になる。

\section{III-2 焼結の進行}

圧縮された線同士が焼結する時，まず接触面が接合す ると考えられるので, 加圧によって変形・接触した部分 の焼結率について，時間による変化を調べた． $1263 \mathrm{~K}$,
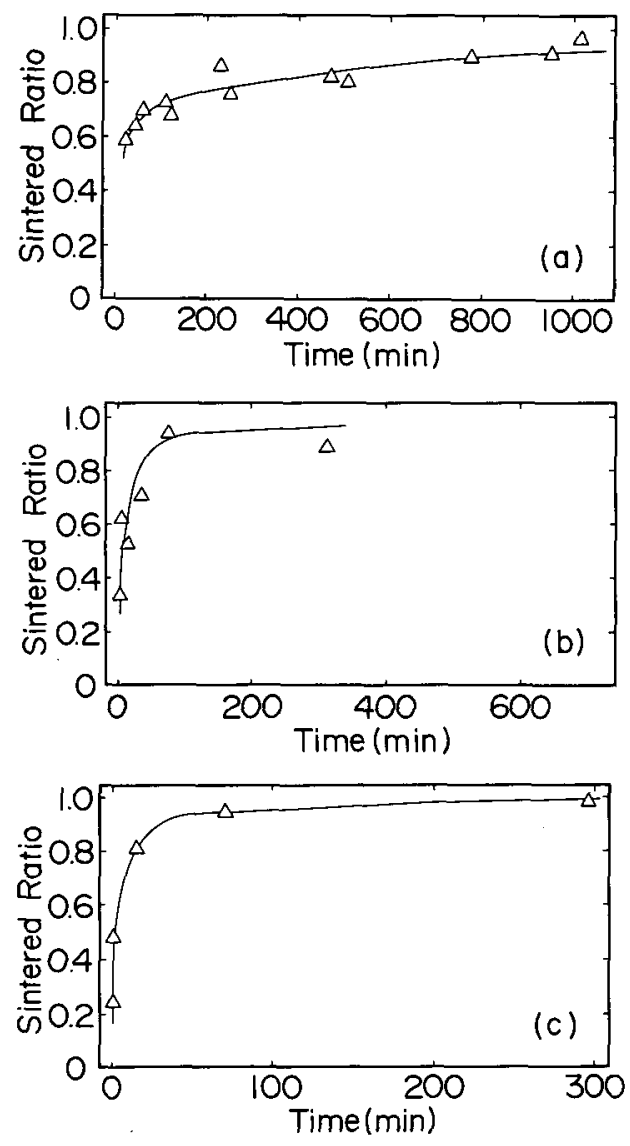

Fig. 8 Change of the sintered ratio with the time.
(a) sintered at $1263 \mathrm{~K}$
(b) sintered at $1363 \mathrm{~K}$.
(c) sintered at $1463 \mathrm{~K}$

及び $1363 \mathrm{~K}, 1463 \mathrm{~K}$ に打ける焼結率対時間の曲線を Fig. 8 (a)〜(c) に示す.これによれば，いずれの温度で も焼結率は初急速に増加し，その後ゆるやかに1.0に 漸近する．そのときの接触面の变化を見ると，Fig. 9 の 光学顕微鏡写真に示すように，面内のいくつかの箇所で 生じた微視的結合が成長するに伴い，間に存在する細 な气気孔が次第に消滅し，接合面が接触面全体に広がった。 III-3 焼結の活性化エネルギー

各温度に和ける焼結率対焼結時間の曲線 Fig. 8 から焼 結率0.6及び 0.9 の場合の $1 \mathrm{nt}$ 対 1/T の関係を求めて Fig. 10 を得た．温度の点は少ないが，このプロットを直線 とみなして算出した活性化ェネルギーは，焼結率0.6で

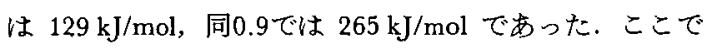
焼結率0.6に対する值はステンレス鋼中の鉄の粒界拡散 の活性化エネルギー $(180 \mathrm{~kJ} / \mathrm{mol})$ よりかなり小さく，他 方，焼結率0.9に対する值は同じくステンンス鋼中の鉄 の体積抾散の活性化エネルギー $(284 \mathrm{~kJ} / \mathrm{mol})$ にかなり近 い値である4).

\section{III-4 焼結中の加圧力の影響}

焼結中に大きな圧力を加えるとホットプレスで知られ ているよらに緻密化が促進される，しかし，焼結ひずみ の防止を目指して圧粉体の上に載せたセラミックス製治 具などによる小さな力は，効果を調べた例が見当たらな い.そこで， $2910 \mathrm{~g} \sim 5820 \mathrm{~g}$ の鉦を載せた状態で焼結し た結果が Fig. 11 である。同図は倛結前の線間の接触平 面に加わる焼結中の俚力に対して焼結率を示している. これによれば $5 \mathrm{MPa}$ までの圧力は焼結率に影響しない、 が，それ以上では圧力とともに焼結率が上昇した。

\section{III-5 宽結の進行に及ぼす線径の影響}

一般に粉末の焼結は, 粗粉末に比べて微粉末の方が進 行が速いと言われている5) ので， $\phi 0.035 \mathrm{~mm}$ の線を用い た結果を $\phi 0.160 \mathrm{~mm}$ の場合と比較した。をず $\phi 0.035$ $\mathrm{mm}$ の線を用いた試料を $1263 \mathrm{~K} て ゙ 22 \mathrm{~min}$ 及び $232 \mathrm{~min}$, また $1463 \mathrm{~K}$ では $0.22 \mathrm{~min}$ 及び $14 \mathrm{~min}, 294 \mathrm{~min}$ 焼結し て焙結率を求め, $\phi 0.160 \mathrm{~mm}$ の試料と比較した結果を Fig. 12 に示す. 同図では焼結温度と時間を桩散量に比 例するDtにまとめて括り, 同図(b)はDtが小さい段階 の詳細図である、ただし，Dを求めるための D。及び Q としては18-8ステンレス鋼中の鉄の拡散に対する值, $\mathrm{D}_{\mathrm{o}}=0.58 \mathrm{~cm}^{2} / \mathrm{sec}$ 及び $\mathrm{Q}=67.1 \mathrm{kcal} / \mathrm{mol}$ を用いた

Fig. 12 による Dt の小さい焼結初期では焼結率に線 径の影響は認められなかった。しかし Dt の大きい高温 ・長時間側では, $\phi 0.160 \mathrm{~mm}$ の試料の焼結率が 1.0 亿漸 近し, 本研究の範围では1.0以上になっていないのに対 し, $\phi 0.035 \mathrm{~mm}$ の試料のそれは1.0を越えて上昇してい た.

次に, このよらに線径の異なる2種の試料について, 接触部に生じたネックの外表面（切断面で見るネックの 


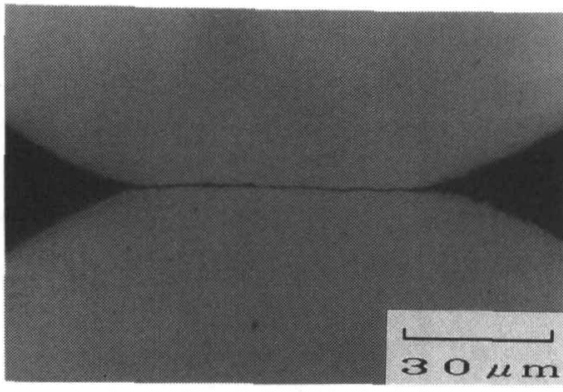

(a)

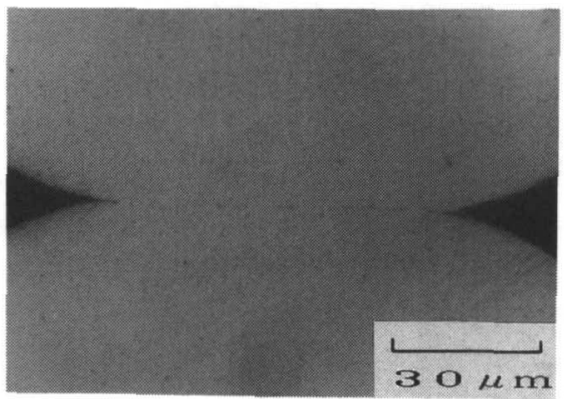

(b)

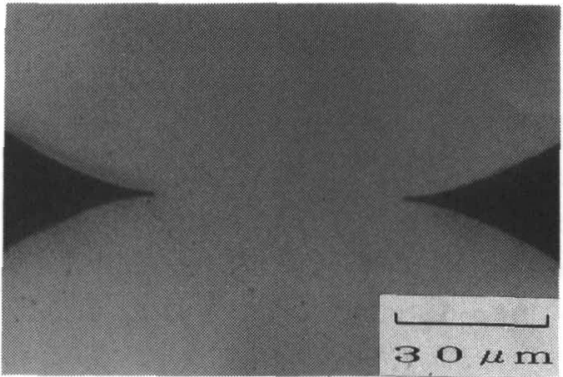

(c)

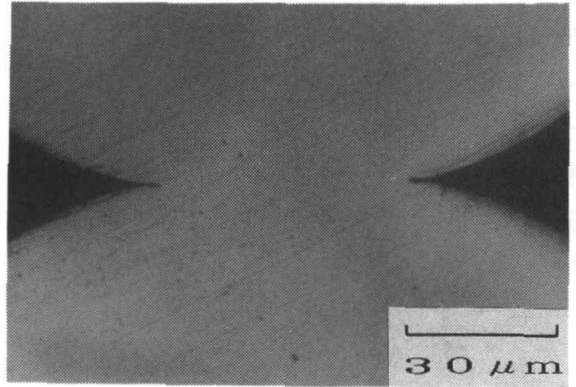

(d)

Fig. 9 Progress of sintering between contacting surfaces.
(a) before sintering
(b) sintered at $1263 \mathrm{~K}$ for $52 \mathrm{~min}$
(c) sintered at $1263 \mathrm{~K}$ for $509 \mathrm{~min}$
(d) sintered at $1263 \mathrm{~K}$ for $776 \mathrm{~min}$

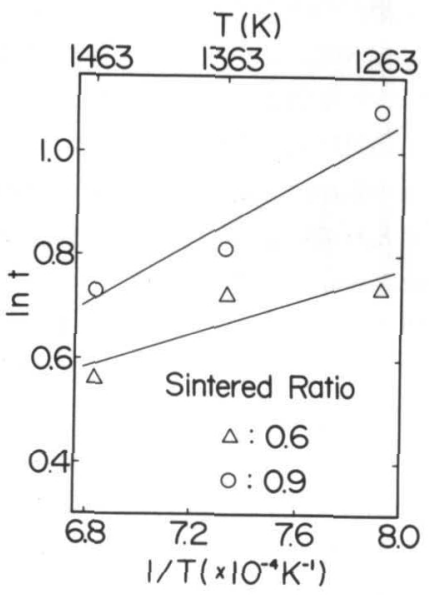

Fig. 10 The $\ln t$ versus $1 / \mathrm{T}$ relations for sintered ratios of 0.6 and 0.9 .

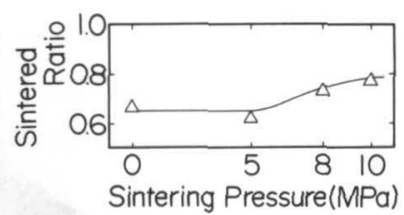

Fig. 11 Change of the sintered ratio with the pressure applied during sintering at $1263 \mathrm{~K}$ for $52 \mathrm{~min}$.
両端）の曲率半径を比較した。ここでは $\phi 0.160 \mathrm{~mm}$ 及 び $\phi 0.035 \mathrm{~mm}$ の試料の内, $1263 \mathrm{~K} て ゙ 30 \mathrm{~min}$ 焼結したも のと, $1463 \mathrm{~K}$ で $5 \mathrm{hr}$ 焼結したものについて調査した. その結果, ネック表面の曲率半径の測定値は大きくばら ついたが, 平均値に注目すると, Fig. 13 に示すよらに 焼結条件が等しけれぱほぼ等しい値となり, 線径に関係 ないことが分かった。

$$
\mathrm{N} \text { 考察 }
$$

$\mathrm{N}-1$ 焼結の進行

加圧によって変形・接触した面で焼結前に起こると予 想される再結晶や粒成長の段階を, 本実験では別個に調 査してはいないが, 時間によるネック輪郭の変化をまと めれば, 焼結は次のように進行していると考えられる6).

変形した鋼線の接触面は一見平坦で完全に接触してい るよらに見えるが，実際は Fig. 14 (a) のよらに細かな凹 凸を持ち, 微視的な真の接点と微細な空陌によって構成 されているであろう. 微視的接点では試料が焼結温度に 加熱されると, 再結晶及び粒成長の後, 原子移動が表面 積を隇少させる方向に進むので, ごく短時間に接合が起 こると思われる. 次に微視的接合面で取り囲まれた接触 面中の気孔に注目すれぱ, 表面張力が働き, 同図 (c) の ように丸みを帯び, (d) のように球形になり,さらに (e) 

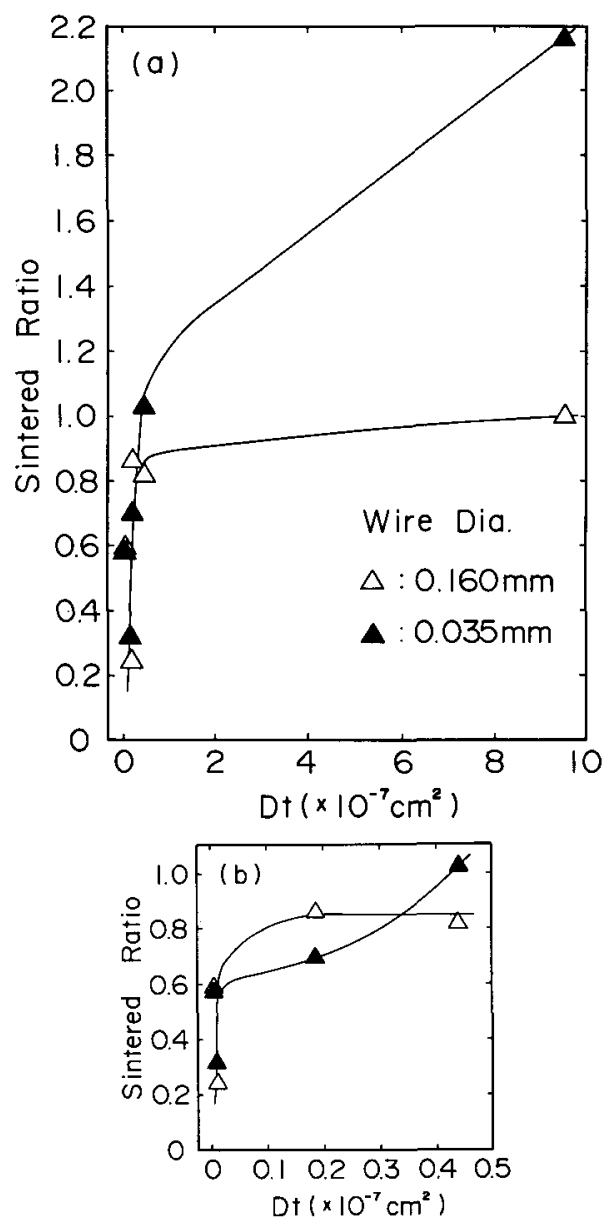

Fig. 12 The sintered ratio versus Dt relations in $0.160 \mathrm{~mm}$ and $0.035 \mathrm{~mm}$ wire compacts.

(a) all the obtained data

(b) enlarged figure of (a)

のように消隇するであろう，その時の原子の移動機構を 論じるには，調查した温度の数が少ないが，一応，本㬰 験の範囲内では温度によって機構が変化しないと考えて みる。そうすれば，接触面の結合中期（焼結率=0.6） までの段階では，活珄化エネルギーが粒界桩散の值より 若干小さいことから，表面拡散が寄与しているであろう と推測される、結合が後期（焼結率＝0.9）になると活

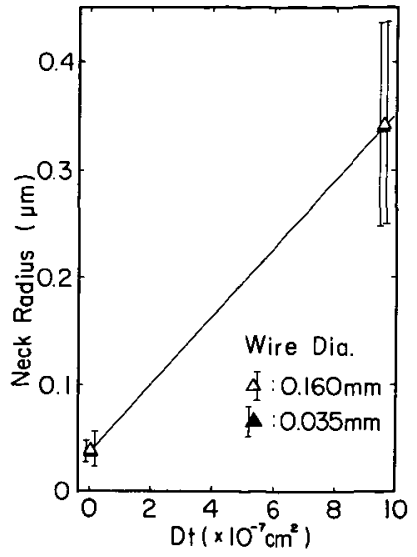

Fig. 13 The neck radius versus $D t$ relations in $0.160 \mathrm{~mm}$ and $0.035 \mathrm{~mm}$ wire compacts.

性化エネルギーが大きくなるから，体積払散機構が主と 考克られる。このように結合の度合が高い段階で活性化 エネルギーが大きくなる傾向は，ステンレス鋼粉の㸁結 データでも認められている》。

$\mathrm{N}-2$ 一軸圧力に上る焼結の促進

接触して变形した 2 つの線の間には，加圧・除荷に伴 らスプリングバックで微視的間隙が生じて拉り，むし焼 結中にある程度以上の圧力が加えられると，再接触した 面で微視的気孔の減少と真の接触面積の増加が起こるで あ万う。このような圷力は焼結の促進をるたらすと期待 され，本実験の焼結中に影響が見られ始める圧力 5 MPa がその变形に必要な圧力の下限值と考えられる. 参考までに SUS304のクリープ強度を見ると， $1089 \mathrm{~K}$ ・ クリープ速度 $0.00001 \% / \mathrm{hr}$ 深括いて約 $7.84 \mathrm{MPa}$ であ

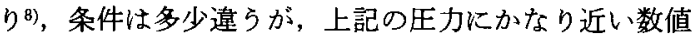
であった。

\section{$\mathrm{N}-3$ 烸結の進行に及注す線径の影響}

加圧によって変形・接触した線同士が焼結するとき， まず前述のような過程を経て接触面の接合が起こると考 えられる。この段階では接触面内部におけける接合過程で あるため,進行状況に線径による違いはなない予想され， それは Fig. 12 に扣いて䖢結率1.0以下の場合に，線径の

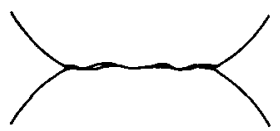

(a)

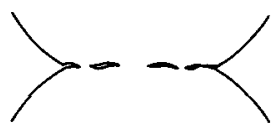

(b)

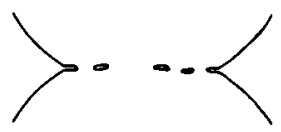

(c)

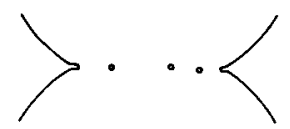

(d)

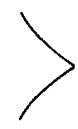

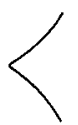

(e)

Fig. 14 Illustration of the sintering process which begins at (a) and ends at (e). 


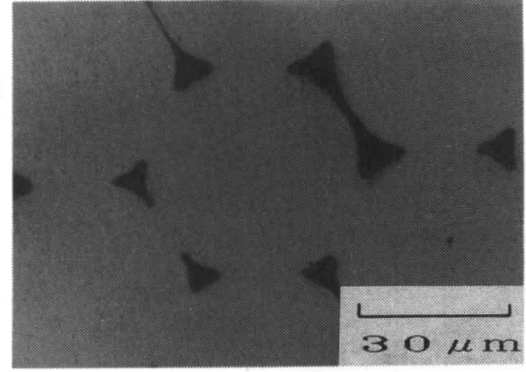

(a)

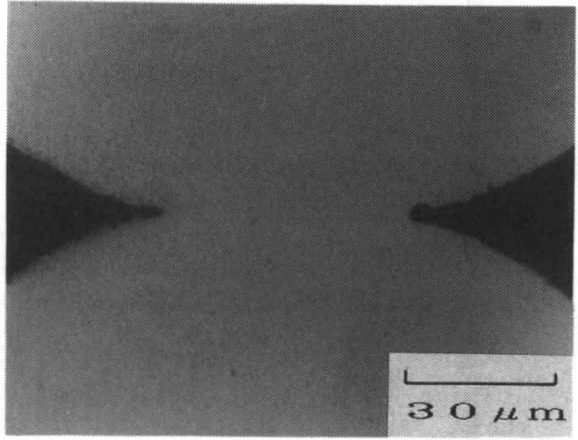

(b)

Fig. 15 Necks after sintering at $1463 \mathrm{~K}$ for $5 \mathrm{hr}$. (a) $0.035 \mathrm{~mm}$ wire compact (b) $0.160 \mathrm{~mm}$ wire compact

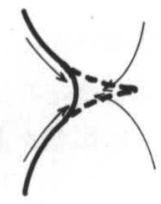

(a)

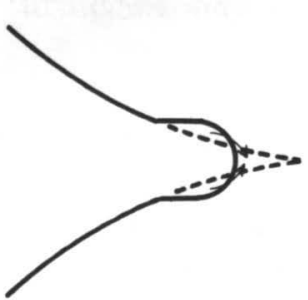

(b)

Fig. 16 Diffusing routes of atoms for the neck growth

(a) $0.035 \mathrm{~mm}$ wire compact

(b) $0.160 \mathrm{~mm}$ wire compact

影響が見られないことによって確かめられる.

次に接触面の接合が完了してネックの外側が丸みを帯 びる方向に進むとき，同じ焼結条件ではネック外周の曲 率半径が線径に関係なく等しかったのに対し, 外周との つながり方には差がみられた. 寸なわち， $\phi 0.035 \mathrm{~mm}$ の試料では Fig. 15 (a) に示すよ5に線の外形の円弧にネ ック部分の曲線が滑らかにつながっているのに対し, $\phi 0.160 \mathrm{~mm}$ の試料では同図 (b) のように一見ネック両端 で線間に未焼結部分が存在して, その間隙が拡大してい るよらな形になっていた.これは, $\phi 0.035 \mathrm{~mm}$ の試料 ではネック自体の曲率半径が線径と比ぺて 1 桁程度しか 違わないため, ネックに向から原子の発生源がネック付 近に限定されず, Fig. 16 (a) のよらに線全体から原子が 移動してくるのであろら. 他方, $\phi 0.160 \mathrm{~mm}$ の試料で はネック部分が原子で埋められるとき，Fig. 16 (b) のよ らにネック付近から原子が移動してくると考えられる. その結果, $\phi 0.035 \mathrm{~mm}$ の試料ではネックが外側になめ らかに連なる形に成長するが， $\phi 0.160 \mathrm{~mm}$ の試料では 原子の移動がネック付近のみで起こり, 外側との境界が 消失しないと思われる.

\section{V 結 論}

ステンレス鋼巻線試料を軸に平行に冷間加圧し，線同 士の間で圧縮変形によって生じた接触面の接合過程につ いて各種焼結条件の影響を調査した. 結果は次の通りで ある。

(1)接触面の接合は初め急激に起こり, その後緩やかに進 行した. そのときまず面内のいくつかの箇所で微視 的に接合が生じ，その成長に伴って間に存在する微視 的気孔が消滅し, 接合面が接触面全体に広がっていっ た.

(2)接触面が $60 \%$ 接合するまでの焼結の活性化エネルギー はステンレス鋼中の鉄の粒界拡散に括ける值より小さ かった．また，90\%接合するまでの焼結の活性化エネ ルギーはステンレス鋼中の鉄の体積拡散における值に 近かった.

(3)焼結中に加圧力を与えると $5 \mathrm{MPa}$ 以上でその効果が 見られた。

(4)線径の異なった試料を用いても，接触面の接合段階で は両者の焼結速度に違いは見られなかった. しかしそ の後のネックの成長段階は, 線径の小さい試料の方が 大きな試料に比べて速く起こった.

(5)焼結条件が等しければ, ネック外周の曲率半径は線径 に関係なく等しい値を示した。

本研究を発表するに際し, 広島大学の卒業研究として 精力的に実験された北山敏史（現在東洋紡珠）及び大橋 達弘（現在三菱重工侏）の両氏，ステンレス鋼粉の焼結 に関する討論に応じて下さった九州大学工学部の徳永洋 一教授及び鎌田政智助手, また試料鋼線を提供された日 本精線侏に厚くお礼申し上げます。

\section{文献}

1) B. H. Alexander and R. W. Balluffi : Acta Met., 5 (1957), 
666 .

2) M. Slesar, E. Dudrova, L. Parilak, M. Besterci and E. Rudnayova: Sci. of Sintering, 19 (1987), 17.

3) P. Guiraldenq：Diffusion les Metaux (技術者の抬敬入門), 平 野・岡田訳 (1984), 113, 共立出版.
4）増本：ステンレス鋼便覧 (1973)，32，日刊工業新聞社.

5) F. V. Lenel : Powder Metallurgy (1980), 218, M. P. I. F.

6）若林・渡辺：新版粉末治金 (1976), 31，技術書院.

7) R. M. German: Metallurgical Trans. A, 7A (1976), 1879.

8）牟田：ステンレス鋼便覧 (1973), 432, 日刊工業新聞社. 